\title{
Geography and decolonisation
}

\author{
Daniel Clayton and M. Satish Kumar
}

\begin{tabular}{|l|l|}
\hline Date of deposit & 22112019 \\
\hline Document version & Author's accepted manuscript \\
\hline Access rights & $\begin{array}{l}\text { Copyright C } 2019 \text { Elsevier Ltd. All rights reserved. This work is } \\
\text { made available online in accordance with the publisher's policies. } \\
\text { This is the author created, accepted version manuscript following } \\
\text { peer review and may differ slightly from the final published } \\
\text { version. }\end{array}$ \\
\hline $\begin{array}{l}\text { Citation for } \\
\text { published version }\end{array}$ & $\begin{array}{l}\text { Clayton, D., \& Kumar, M. S. (2019). Geography and } \\
\text { decolonisation. Journal of Historical Geography, 65. }\end{array}$ \\
\hline $\begin{array}{l}\text { Link to published } \\
\text { version }\end{array}$ & https://doi.org/10.1016/j.jhg.2019.10.006 \\
\hline
\end{tabular}

Full metadata for this item is available in St Andrews Research

Repository at: https://research-repository.st-andrews.ac.uk/

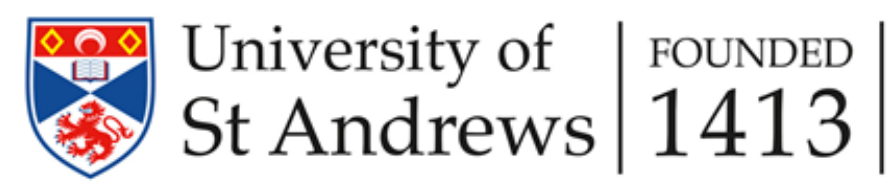




\section{Geography and decolonisation}

The five papers in this special issue consider geography's important but little studied connections with post-war decolonisation. Three of them - by Eliot Child and Trevor Barnes; Ruth Craggs and Hannah Neate; and Hannah Fitzpatrick - stem from two themed sessions on this association that we convened at the 2016 RGS-IBG Annual Conference in London, and with a focus on the so-called 'third wave' of decolonisation (1945 - c.1980) starting in Southeast Asia and the Middle East, and then stretching across Africa, the Pacific and Caribbean. ${ }^{1}$ Two further papers - by João Sarmento and Marie-Albane de Suremain - were sought by us, chiefly to furnish a greater range of coverage and debate across French and Portuguese as well as American and British trajectories, experiences and situations of decolonisation.

This introduction to the suite of papers seeks to do four things. First, and to explain the motives behind the conference sessions and now this special issue, we point to the ambiguous and skewed place that the subject of decolonisation has within geographic thought and scholarship, and how scant historical attention has been paid to how geography and geographers were involved in the post-war dissolution of colonial empires. Second, we note how such abstruseness might be related to a more general set of conceptual and semantic difficulties surrounding the term decolonisation. Third, and

\footnotetext{
'Historians distinguish between four 'waves' or 'phases' of decolonisation: the first pertaining to the American and French Revolutions, dissolution of Portugal's and Spain's New World empires, and the overthrow of slavery; the second with reference to the reconfiguration of European colonial empires and the redrawing of the map of Europe after World War I; and the fourth in connection with the demise of communism (state socialism) in Eastern Europe and the Soviet Union from 1980 - although it is also emphasised that each of these waves or phases of decolonisation were entangled with new projects of colonisation. See R. Betts, Decolonization: A brief history of the word, in: E. Bogaerts and R. Raben (Eds), Beyond Empire and Nation: The Decolonization of African and Asian Societies, 1930s-1970s, Leiden, 2012, 23-38; J. Burbank and F. Cooper, Empires in World History: Power and the Politics of Difference, Princeton, 2010, 228-260, 413-454; R.J.C. Young, Empire, Colony, Postcolony, New York, 103-115
} 
with this backdrop in mind, we try to identify links between the papers and the larger issues that arise from the specific stories they tell. And fourth, we use this focus to point to the need for further work on the broader spatiality of decolonisation.

\section{Decolonisation between history, theory and the present}

Our initial motivation for this project was to respond to the recognition that while there is a large, rich and eclectic critical literature on the relations between geography and empire, and the long shadow that this imbroglio casts over geography's disciplinary identity and public image, barely any of it deals with the era of post-war decolonisation. This literature is overwhelmingly forked between either a focus on the colonial past, or a concern with contemporary forms of imperial 'duress' (to use Ann Stoler's terms), and with negligible attention, except in the most generalised of ways, with what passes between the two. ${ }^{2}$ Post-war decolonisation receives remarkably short shrift in geography textbooks and surveys of geographic thought as well as in specialist research on geographies of colonialism and empire past and present. And the few geographers who have written about post-war decolonisation largely ignore other geographers' work on the subject and its bearing on the discipline. ${ }^{3}$

Achille Mbembe argues that there has been much too little engagement with how and why 'the genealogy of the contemporary world - a world plagued by ever-increasing inequality, militarization, enmity, and terror, as well as by a resurgence of racist, fascist, and nationalist forces determined to exclude and kill' - revolves around 'the desires, fears, affects, relations, and violence that drove colonialism', and how these drives

\footnotetext{
${ }^{2}$ A.L. Stoler, Duress: Imperial Durabilities in Our Times, Durham NC, 2016.

${ }^{3}$ See R.A. Butlin, Geographies of Empire: European Empires and Colonies c.1880-1960, Cambridge, 2009, 577-610.
} 
extend and mutate through turbulent histories of decolonisation that reach into the present, and legacies that cannot simply be termed colonial. ${ }^{4}$ Accordingly, in largely bypassing the era of post-decolonisation, the geographical literature on empire arguably truncates understanding of the arc of geography and empire from the past to the present, and of the question of whether it is possible the draw a clear or straight line between a geography that was once complicit in empire and one that is now not (or at least one that now has the wherewithal and determination not to be).

A second, related, motivation was our disgruntlement with what we see as a mismatch between two emerging ways of dealing with the idea decolonisation - one focused on its post-war history, the other theoretically-oriented and more historically irresolute. One the one hand, over the last twenty years there has been a resurgence of interest in the 'third wave' of decolonisation across diffuse research areas environmental, cultural, 'new imperial', military and transnational history; and Cold War, development, globalisation, indigenous and settler colonial studies - and with some major surveys and syntheses in recent years. ${ }^{5}$ There are a number of reasons for this, that we will not go into here, but not least of which has been the steady release into the public domain of hitherto closed (official and secret) dossiers relating to the era of decolonisation which bring the violence of this process out into the open. This recent

\footnotetext{
${ }^{4}$ A. Mbembe, Necropolitics, Durham NC, 2019, cover.

P. Blanchard, N. Bancel and S. Lemaire, La fracture coloniale: la société française au prisme de I'héritage colonial, Paris, 2005; E. Buettner, Europe After Empire: Decolonization, Society, and Culture, Cambridge, 2016; O. Le Cour Grandmaison, La République impériale: politique et racsime d'État, Paris, 2009; A.G. Hopkins, American Empire: A Global History, Princeton, 2018; M.B. Jerónimo and A.C. Pinto (Eds), The Ends of European Colonial Empires, London, 2015; S. Mawby, Ordering Independence: The End of Empire in the Anglophone Caribbean, 1947-69, Basingstoke, 2012; P. Oliveira, Os Despojos da Aliança. A Grã-Bretanha e a Questão Colonial Portuguesa 1945-1975, Lisbon, 2007; P. Seale, The Struggle for Arab Independence: Riad el-Solh and the Makers of the Modern Middle East, Cambridge, 2010; M. Thomas, Fight or Flight: Britain, France, and Their Roads From Empire, Oxford, 2014; M. Thomas, B. Moore and L.J. Butler (Eds), Crisis of Empire: Decolonization and Europe’s Imperial States 1918-1975, London, 2008.
} 
range of work exceeds and reworks past attempts to evaluate the relative importance of economic, political, ideological and moral factors in decolonisation, while retaining the core emphasis in prior literature on how this process involved diverse and often conflicting metropolitan and colonial desires and ambitions, and could mean markedly dissimilar things to peoples and regions with different places and stakes in colonial, postcolonial and post-imperial hierarchies. ${ }^{6}$

This new literature pursues what Aimé Césaire, in his 1950 Discours sur le colonialism, one of the most incisive and influential works of anti-colonial criticism, famously identified as the choc en retour (boomerang effect - aftershocks) of empire on both the colonising and the colonised. ${ }^{7}$ There is renewed concern with how empire 'came home' to Europe through both hopeful and harrowing webs and realities of displacement, identity loss, immigration, memory (colonial amnesia and nostalgia), racism and transnational solidarity, and how new fluidities - corporeal transactions, diasporas, psychic remains of empire and anticolonial visions of change - continued to connect ex-colonies and former imperial centres of power. ${ }^{8}$ Parts of this literature dwell on the physical and psychological violence and scars of decolonisation associated with

\footnotetext{
${ }^{6}$ Some important antecedents to current debates can be found in F. Bernault, Démocraties ambigües en Afrique centrale: Gabon, Congo-Brazzaville, 1940-1965, Paris, 1996; F. Cooper, Decolonization and African Society: The Labor Question in French and British Africa, Cambridge, 1996; J. Darwin, Britain and Decolonization: The Retreat from Empire in the Post-War World, London, 1988; R.F. Holland, European Decolonization, 1918-1981: An Introductory Survey, London, 1985; D. Low and J. Lonsdale, Introduction: towards the new order, 1945-1963, in: D. Low and A. Smith (Eds), The Oxford History of East Africa, Volume III, Oxford, 1976, 1-64; W.R. Louis and R. Robinson, The imperialism of decolonization, Journal of Imperial and Commonwealth History, 22 (1994) 462-511. ${ }^{7}$ A. Césaire, Discours sur le colonialisme, Paris, 1950.

${ }^{8}$ See F. Bernault, Colonial Transactions: Imaginaries, Bodies, and Histories in Gabon, Durham NC, 2019; R. Coelho, An archaeology of decolonization: imperial intimacies in contemporary Lisbon, Journal of Social Archaeology 19 (2019) 181-205; R. Gildea, Empires of the Mind: The Colonial Past and the Politics of the Present, Cambridge, 2019; P. Gleijeses, Visions of Freedom: Havana, Washington, Pretoria and the Struggle for Southern Africa, 1976-1991, Chapel Hill NC, 2013; B. Stora, La gangrène et l'oubli: La mémoire de la guerre d'Algérie, Paris, 1998; M. Matera, Black London: The Imperial Metropolis and Decolonization in the Twentieth Century, Berkeley, 2015; C. Tshimanga, D. Gondola and P. Bloom (Eds), Frenchness and the African Diaspora, Bloomington, 2009; S. Ward (Ed), British Culture and the End of Empire, Manchester, 2001.
} 
both retreating colonial power (with bloody wars and guerrilla insurgencies, and 'gulags' of torture and abuse), and in relation postcolonial leaders, states and elites, which were sometimes no less authoritarian, belligerent, corrupt or divisive than their colonial forebears (and with debate here about the extent to which colonialism is culpable, and whether postcolonial states that had been under direct imperial control were more or less likely to thrive economically or become more egalitarian than those that had been under indirect rule) ${ }^{9}$

Surrounding this body of work, a growing portion of which is comparative and seeks to bring metropole and colony into a single analytical space, is a concern with how decolonisation intersected with Cold War geopolitics and the global reach of a 'new imperialism' of development and modernisation that revolved, in good measure, around the United States of America (USA). ${ }^{10}$ Discussion of the overlaps, differences and tensions between ideas of development and decolonisation has long been a noteworthy facet of how post-war imperial dissolution has been comprehended. To European colonial powers, 'development' (and the scientific knowledge and understanding

\footnotetext{
${ }^{9}$ On violence, see D. Anderson, Histories of the Hanged: Britain's Dirty War in Kenya and the End of Empire, London, 2005; C. Elkins, Britain’s Gulag: The Brutal End of Empire in Kenya, London, 2005; R. Branche, La torture et l'armée pendant la guerre d'Algérie 1954-1963, Paris, 2001; B. Greiner, War Without Fronts: The USA in Vietnam, London, 2009; K. Hack, Decolonization and violence in Southeast Asia: crises of identity and authority, in: E. Bogaerts and R. Raben (Eds) Beyond Empire and Nation: The Decolonization of Asian and African Societies, 1930s-1970s, London, 137-166. On the fissures and violence of the postcolonial state, see G. Apata, Corruption and the postcolonial state: how the West invented African corruption, Journal of Contemporary African Studies 37 (2019) 43-56; A. Gupta, Bureaucracy, Structural Violence and Poverty in India, Durham NC, 2012; M. Lange, Lineages of Despotism and Development: British Colonialism and State Power, Chicago, 2009.

${ }^{10}$ For overviews of this international perspective on decolonisation, and how many of the roads taken culminated in the Vietnam War, see M. Connelly, Taking off the Cold War lens: visions of NorthSouth conflict during the Algerian War of Independence, American Historical Review, 105 (2000) 739 769; N. Cullather, The Hungry World: America's Cold War Battle Against Poverty in Asia, Cambridge MA, 2010; P. Gleijeses, Decolonization and the Cold War, in: M. Thomas and A. Thompson (Eds), The Oxford Handbook of the Ends of Empire, Oxford, 2018, https://www.oxfordhandbooks.com/view/10.1093/oxfordhb/9780198713197.001.0001/oxfordhb9780198713197; F. Logevall, Embers of War: The Fall of an Empire and the Making of America's
} Vietnam, New York, 2013. 
supposedly underpinning it) was a rhetoric and apparatus of power that helped dying colonial empires to reinvent themselves in a less aggressive guise, and helped the USA to camouflage the exploitative side of its modernisation missions overseas, as well as deflect attention from its empire over Native peoples at home. ${ }^{11}$ Wolfgang Sachs observes that 'Like a towering lighthouse guiding sailors towards the coast, "development" stood as the idea which oriented emerging nations in their journey through post-war history. No matter whether democracies or dictatorships, the countries of the South proclaimed development as their primary aspiration, after they had been freed from colonial subordination'. ${ }^{12}$ And taking a longer-term and 'tragic' perspective, Talal Asad claims that a 'new world has been forcibly created as a consequence of the West's imperial adventure' and returns to the question of violence, in this case as the creeping and now pervasive 'force' of modernity: 'Essentially the West has become a vast moral project, an intimidating claim to write and speak for the world, and an unending politicization of power' ${ }^{13}$

Across this literature there is a thoroughgoing reckoning with post-decolonisation as a project of both hope and despair, fulfilment and disillusionment, and revolution and evolution. It is to the image of decolonisation as an imperfect, harrowing and melancholic process of change, rather than as a quick, complete or progressive escape from empire, that it repeatedly turns. Thinking and scholarship about this 'dark side' of decolonisation contains strong political, conceptual and ethical messages: that this is an

\footnotetext{
${ }^{11}$ See M. Rahnema, Introduction, in: M. Rahnema and V. Bawtree (Eds), The Post-Development Reader, London, 1997, 10. Also see D. Immerwahr, How to Hide an Empire: A Short History of the Greater United States, London, 2019; U. Kothari, Spatial practices and imaginaries: Experiences of colonial officers and development professionals, in: M. Duffield and V. Hewitt (Eds), Empire, Development and Colonialism: The Past in the Present, Suffolk, 161-175.

${ }^{12}$ W. Sachs, The Development Dictionary: A Guide to Knowledge as Power, London, 1992, 2.

${ }^{13}$ T. Asad, Conscripts of western civilization? in: C. Gailey (Ed), Dialectical Anthropology: Essays in Honor of Stanley Diamond, Volume 1, Gainesville FL, 1992, 345. On Asad's 'tragic sensibility', see D. Scott, Revolution/theory/modernity: notes on the cognitive-political crisis of our time, Social and Economic Studies 44 (1995) 1-23.
} 
infinite project, and that to evaluate how its unfinished history reverberates in the present, one needs to historicise, and, more particularly, return to its human stories of optimism and desolation, amity and enmity, privilege and abandonment, and candour and mendacity, as well as to the policies and power structures that sent decolonisation along particular paths. ${ }^{14}$

On the other hand, talk of decolonisation has also recently resurfaced within geography (and other areas of study) in ways that put the idea on a different, more abstract and contemporary (albeit still politicised), track. Geographers are working with 'the decolonial' as a theoretical construct, and the verb 'decolonise' as a concept metaphor, or loose marker of what we want to improve about our societies and professional codes and institutions ('decolonising' curricula, disciplines, imaginaries, methodologies and geographical knowledges). ${ }^{15}$ There are many merits to the theoretical and methodological manoeuvres associated with these two terms. A veritable concern with how academic work and disciplines 'de-link' from dominant power structures (become less white, Western, male, for example) and foster more hopeful geographies lies at the heart of them. However, they start to fall foul of decolonisation as a historical phenomenon involved myriad struggles when they become too tightly bound up with intellectual and disciplinary angst about how to take a critical stand. And what, we have wondered (without wishing to get into the matter in any detail here), is the difference between a 'decolonial' and 'postcolonial' critique, and does such a difference matter? ${ }^{16}$ Is the former a hazily historicised substitute for the latter? Is 'the decolonial' any more

\footnotetext{
${ }^{14}$ See A. Moreiras, Beyond the line: on infinite decolonization, American Literary History 17 (2005) $575-594$.

${ }^{15}$ See, S. Radcliffe (Ed), Themed intervention: decolonising geographical knowledges, Transactions of the Institute of British Geographers 42 (2017) 329-348.

${ }^{16}$ See, for example, A. Murray and N. Jackson, A decolonial critique of the racialized 'localwashing' of extraction in Central Africa, Annals of the Association of American Geographers (2019) https://www.tandfonline.com/doi/full/10.1080/24694452.2019.1638752
} 
attuned (as a category or critical stance) than 'the postcolonial' to grappling with and dismantling what Walter Mignolo and other 'decolonial' thinkers describe as the 'colonial matrix of power': 'the inextricable combination of the rhetoric of modernity (progress, development, growth) and the logic of coloniality (poverty, misery, inequality)', as Gurminder Bhambra captures this formulation. ${ }^{17}$

In our view, many 'decolonial' and 'decolonising' projects within geography reflect too briefly on their historical hue and geographical specificity: how the former has its roots in Latin American histories of decolonisation and dependency and begs a set of questions about how well the matrix it arraigns fits decolonising Africa and Asia 150 years later; and how the latter revolves around struggles, pedagogies and imperatives of reconciliation in what Robert Young dubs 'settler postcolonies' - generally 'the most politically stable [of] postcolonial states ... in the Americas and Oceania peopled by immigrant Europeans... [but] marked by one significant element: the presence of indigenous peoples', and peoples who have been illiberally treated and genocidally expunged, and have a subordinate status in the matrix of the postcolony. ${ }^{18}$ In other words, the terms 'decolonial' and 'decolonising' have complex histories and geographies. At worst, loose usage of these terms runs the risk of fostering what Seloua Boulbina describes as a 'low cost decolonisation' that overlooks and may detract from the gravity of post-war decolonisation, and at a time when history in general is being flatlined (or 'shipwrecked', to use Mark Lilla's evocative term) by populist and reactionary imaginaries and practices that nurture a 'post-truth' politics that is producing sanitised,

\footnotetext{
${ }^{17}$ W. Mignolo, Coloniality of power and de-colonial thinking, Cultural Studies 21 (2007) 155, paraphrasing the Peruvian philosopher Aníbal Quijano; G. Bhambra, Postcolonial and decolonial dialogues, Postcolonial Studies 17 (2014) 119.

${ }^{18}$ Young, Empire, Colony, Postcolony, 142. Also see M. Daigle and J. Sundberg, From where we stand: unsettling geographical knowledges in the classroom, Transactions of the Institute of British Geographers 42 (2017) 338-341.
} 
simplified, distorting and mendacious views of how the present finds itself in the past (as a foreboding or longing) ${ }^{19}$ Others worry that the 'decolonial' springs from a utopian quest (and for some fantasy): the countenancing and harbouring of a pure agency, identity or standpoint beyond the reaches of power and that it should not be 'mainstreamed' by disciplines like geography, to use Tariq Jazeel's phrase, or ventriloquised to valorise otherness. ${ }^{20}$

However, to pick our way back to our quarry, when Ruth Craggs recently wrote of 'Decolonising The Geographical Tradition' she had something else in mind. Commenting on the way even vanguard 'critical and contextual' histories of geography such as David Livingstone's 1992 The Geographical Tradition eschewed discussion of postwar decolonisation, she gestured towards a larger claim: that geographers have been more eager, and perhaps found it easier, to plot their discipline's historical imbroglio with empire than explore how geographers in the past might have questioned this entanglement, especially during the post-war decades when the dissolution of colonial empire thrust a sea-change of opinion about matters of freedom and equality upon them..$^{21}$

The five papers in this special issue signpost this question too, and show that geographers were by no means blind to the momentous shift from empire to independence. The scope of the papers is necessarily limited, but they promote lines of enquiry about how geographers from different parts of the world and different sides of colonial and postcolonial divides embraced or abjured change. In our view, such work

\footnotetext{
${ }^{19}$ S. Boulbina, Decolonization, Political Concepts: A Critical Lexicon 5 (2018) http://www.politicalconcepts.org/category/issue-5/; M. Lilla, The Shipwrecked Mind: On Political Reaction, New York, 2016.

${ }^{20}$ T. Jazeel, Mainstreaming geography's decolonial imperative, Transactions of the Institute of British Geography 42 (2017) 334-337. Also see S. de Leeuw and S. Hunt, Unsettling decolonizing geographies, Geography Compass (2018) https://onlinelibrary.wiley.com/doi/full/10.1111/gec3.12376

${ }^{21}$ Ruth Craggs, Decolonising The Geographical Tradition, Transactions of the Institute of British Geographers 44 (2019) 444-446.
} 
has the potential to 'decolonise geography' in media res - that is, from inside the story of its encounter with decolonisation. While many of the storylines in these papers have changed, some of the issues raised for the geographers concerned are not obsolete but persist as palpable legacies and ongoing research challenges and dilemmas. Geographical work in and on the decolonising world presages latter-day debates about how geographies, spaces and spatial dynamics are identified as colonial or colonialist and in need of decolonisation, and what it might take to decolonise to them. The historical angle should not be privileged over all others. But it is important. As Katharyne Mitchell has recently suggested in a wider register, with respect to the imperial 'genealogy' of humanitarian governance within the USA over two centuries, it is important to track apparently current problems and tropes historically and think about the 'interconnected logics' of their past and present configurations. ${ }^{22}$ Or, as Bhambra notes, both 'postcolonialism and decoloniality are developments within the broader politics of knowledge production and both emerge out of political developments' ${ }^{23}$

However, before we discuss the papers we need to register a further difficulty: the ambiguities surrounding the term decolonisation as a post-war phenomenon.

\section{Decolonisation: a 'roomy concept'}

Decolonisation has been deemed a 'roomy concept' describing a 'partial and multi-layered process, comprising different elements, causes and consequences' ${ }^{24}$ It had

\footnotetext{
${ }^{22} \mathrm{~K}$. Mitchell, Education, race and empire: a genealogy of humanitarian governance in the United States, Transactions of the Institute of British Geographers 42 (2017) 349-362.

${ }^{23}$ Bhambra, Postcolonial and decolonial dialogues, 119.

${ }^{24}$ M. Collins, Decolonization, in: J.M. MacKenzie (Ed), The Encyclopaedia of Empire, London, 2016, https://onlinelibrary.wiley.com/doi/full/10.1002/9781118455074.wbeoe360. Also see C. Tolentino, From unincorporated territory to Commonwealth: connecting decolonization and U.S. empire,
} 
been used since the late nineteenth century in a European context, but was not used in connection with post-war Africa and Asia until the 1950s, and then first of all by British and French administrators as an anaemic expression that was designed make the process sound logical and orderly (what the British described as 'managed decline') and deflect attention from its often chaotic, passionate and violent character. ${ }^{25}$ It did not attain the radical intonations it has today until the 1960s, and then through the work of a select number of anti-colonial thinkers, revolutionaries and activists, such as Césaire, Frantz Fanon, George Padmore and Walter Rodney. Fanon, especially, spurred revolutionary usage of the term, opening his 1961 Les damnés de la terre with the claim: 'National liberation, national reawakening, restoration of the nation to the people or Commonwealth, whatever the name used, whatever the latest expression, decolonisation is always a violent event'. ${ }^{26}$ As post-war geographers generally read little of this revolutionary literature, it should come as no surprise that they very seldom used the term. However, this not mean that they did not observe and write about many of the characteristics ascribed to it.

Decolonisation has at least nine meanings and characteristics. First, it connotes the gaining of independence and transfer of power, and how this legal-constitutional event was precipitated. Second, it involved the creation of a tranche of new nation-states (officially equivalent sovereign political entities), and, as Frederick Cooper demonstrates, meant 'the narrative of transition from empire to the nation-state' becoming the lodestar of decolonisation in general, and one that 'became salient only after World War II' ${ }^{27}$ But

\footnotetext{
Mémoire(s), identité(s), marginalité(s) dans le monde occidental contemporain 10 (2013), http://mimmoc.revues.org/1392

${ }^{25}$ J. Darwin, Unfinished Empire: The Global Expansion of Empire, London, 2012, 383; S. Ward, The European provenance of decolonization, Past and Present 230 (2016) 227-260.

${ }^{26}$ F. Fanon, The Wretched of the Earth, translated by R. Philcox, New York, 2004, 1, originally published in French in 1961.

${ }^{27}$ F. Cooper, Citizenship Between Empire and Nation: Remaking France and French Africa, 1945-1960, Princeton, 2014, 2.
} 
third, and as John Darwin neatly observes, this process also yielded 'a constitutional hotch-potch of independent, semi-independent and dependent countries, held together not by formal allegiance to a mother-country but by economic, strategic, political and cultural links that varied greatly in strength and character' ${ }^{28}$ Fourth, and as Fanon mobilised the term, decolonisation evokes the anti-colonial desire to expel foreign influence: a longing and resentment bound up with the long-lived trauma of colonialism, and animating nationalist and independence movements across the globe. Fifth, decolonisation has been characterised as a changing political and intellectual worldview: a switch in focus and priority away from the world of the colonisers to that of the colonised and the plight of post-independence states. Sixth, and as Todd Shepherd notes with reference to anti-colonial, nationalist and black internationalist writers (and the work of figures such as Patrice Lumumba and Rabindranath Tagore), it connotes 'the exploration of dreams, the analysis of struggles, compromises, pledges and achievements, and the rethinking of fundamentals'. ${ }^{29}$ Seventh, and in broad perspective, decolonisation was a sometimes abrupt and in some places protracted, occasionally peaceful and conciliatory but in many places violent and vexed, process of imperial retreat and postcolonial becoming. The narrative on decolonisation encompasses both 'late colonialism' (attempts by Belgium, Britain, France, Portugal and the Netherlands to rejuvenate, reform and defend their colonial empires in the 1940s and 1950s), and what transpired from the moment of independence (a postcolonial era). ${ }^{30}$ Eighth, and in an international frame, the post-war dissolution of colonial empires has been seen as death-

\footnotetext{
${ }^{28}$ J. Darwin, The End of the British Empire: The Historical Debate, Oxford, 2006, 4. ${ }^{29}$ T. Shephard, The Invention of Decolonization: The Algerian War and the Remaking of France, Ithaca and London, 2006, 3-4, 55-81, who further explains that the term was used in France largely in lieu of a better or more frank way of explaining the country's loss of Algeria. Also see D. Chakrabarty, The Calling of History: Sir Jadunath Sarkar and His Empire of Truth, Chicago, 2015; E. Gerrard and B. Kuklick, Death in the Congo: Murdering Patrice Lumumba, Cambridge MA, 2015.

${ }^{30}$ See, J.C. Jansen and J. Osterhammel, Decolonization: A Short History, Princeton, 2017; M. Thomas, Fight or Flight: Britain, France, and Their Roads from Empire, Oxford, 2014.
} 
knell of a centuries-old global order that centred on Europe and the emergence of a new world order pivoting on a global system of nation-states, Cold War bipolarity and projects of international governance and trade and military alliance. Ninth, Kwame Nkrumah was among the first to declare that decolonisation was promulgated as 'neocolonialism': the reconfiguration of Western power and influence in the wake of empire through the intrusion of the state and Western capital and modernisation. ${ }^{31}$

\section{Five stories and situations in the arc of geography and decolonisation}

Akin to our concerns about the rarefied proclivity of 'decolonial geography', scholars such as Cooper have warned of the dangers of doing history backwards - of venturing into the past with today's questions and arguments, and not least about the inadequacies and incompleteness of decolonisation. It is 'not what we now think people should have said in a colonial situation' that matters, he opines, 'but what they actually said, wrote, and did; not the supposedly immanent logics of predetermined types of political regime, but the give-and-take of political actors in a time of profound uncertainty, the words and actions of people who were trying to figure out what they wanted and what they might possibly obtain'. ${ }^{32}$ Geographers were among these actors, sometimes struggling for words, sometimes strident in their views, and studying and advising on both the arts of the possible and the need for decolonising countries and peoples to act in more programmed and grounded ways.

\footnotetext{
${ }^{31}$ K. Nkrumah, Neo-colonialism: The Last Stage of Imperialism, London, 1965. For more on this range of meanings, see F. Cooper, Development, modernization, and the social sciences in the era of decolonization: the examples of British and French Africa, Revue d'Histoire des Sciences Humaines 10 (2004) 9-38; J. Darwin, Decolonization and the end of empire,' in: Robin W. Winks (Ed), The Oxford History of the British Empire, Volume 5: Historiography, Oxford, 1999, 541-557; W. Mignolo, The Darker Side of Western Modernity: Global Futures, Decolonial Options, Durham NC, 2011.

${ }^{32}$ Cooper, Citizenship Between Empire and Nation, 3-4.
} 
The geographers that appear in the five papers that follow worked in different late colonial and postcolonial - situations of decolonisation, held a range of views about the demise of empire and onset of independence, and, akin to Cooper, did not see 'nation-state' or 'development' as the sole or inevitable upshots of change. Neither simply castigating empire nor lamenting its demise, the geographers and geographical projects examined in this special issue underscore the idea that decolonisation resides uneasily and uncannily in social life today as a reminder and provocation to engage with mutations in mechanisms of power that have colonial genealogies: the proliferation of capitalist logistics, governance by credit and the management of pedagogy.

The papers consider the connection between geography and decolonisation in a range of biographical, institutional, national and historiographical terms and contexts: in some cases, with a focus on specific geographers and sites of geographic research, and in others through a concern with how individuals and institutions forged and were shaped by wider disciplinary, political and historical forces and networks. Collectively, the authors are concerned with the diverse and shifting intellectual and political agendas, networks and institutions associated with how geographers' work was undertaken and read. The papers point both to the complexity and variety of decolonisation, and to some of the distinctive ways in which specific geographers, as observers and practitioners immersed in wider networks of expertise and authority, perceived and responded to this process.

We read these papers as works of 'critical and contextual' historical geography that are concerned with the ways and extent to which geographical ideas and practices change as times change (here during an era of rapid political change), and with the importance of thinking through how geographers' claims to truth, configurations of order and reality, and understandings of transformation (here through a project and 
process that wrought a fundamental, if fractured, reallocation of power and reconfiguration of identity) are made and contested in particular places and projects rather than given or immutable. The geographers tracked in the papers - most prominently, Oskar Spate (Fitzpatrick), Akin Mabogunje (Craggs and Neate), Orlando Ribeiro (Sarmento), Jacques Richard-Molard, Paul Pélissier and Assane Seck (Suremain), and others, such as Sherman Kent, a Yale historian-turned-area studies guru (Child and Barnes) - sensed that decolonisation was a rupture in time and Western authority that cracked their discipline's aspiration - and, in some quarters, boast - to provide an accurate, orderly and impartial account of the surface of the earth.

For the most part, the geographers recalled here were working prior to the late 1960s radicalisation of geography with its politicised (Marxist) and putatively progressive lexicon of 'underdevelopment'. But their work was anything but theoretically or politically vapid, and the 1962 evaluation made by New Zealand geographer Keith Buchanan that this generation of geographers, many of them operating in a regional geography-survey mode (he had the likes of Spate in mind) produced work that was 'inadequate for the interpretation of a new, swiftly changing world scene' now seems crude. ${ }^{33}$ For example, in a 1959 report on the future of Fiji commissioned by the colonial government of the islands on the eve of independence, Spate (who had served in Burma and India during World War II) noted that when it came to 'so serious and controversial a subject' as decolonisation geographers needed to get involved and sometime take sides. ${ }^{34}$ As Fitzpatrick shows here, he had taken sides in 1947, preparing maps for the Muslim League which would form part of the territorial case it presented to the Punjab

\footnotetext{
${ }^{33}$ K. Buchanan, West wind, east wind, Geography 47 (1962) 345.

${ }^{34}$ O.H.K. Sapte, The Fijlan People, Legislative Council of Fiji Paper no. 13. Suva, 1959, 101.
} 
Boundary Commission, which delimited the boundary line of the newly independent nation-states of Indian and Pakistan.

Overall, and in the long term, decolonisation augured a significant shift in the way Western geography and geographers viewed the non-Western colonial and postcolonial world. But as these papers show in subtle and illuminating ways in connection with geographers wielding particular pieces of disciplinary machinery (maps, models, fieldwork, regional surveys) this shift did not come overnight, and for the most part the geographers concerned regarded themselves as pragmatic actors rather than high prophets or theorists of decolonisation.

The papers on Nigeria (Craggs and Neate), Angola and Mozambique (Sarmento), Francophone West Africa (Suremain), Undivided India (Fitzpatrick) and the Area Studies programmes in the USA (Child and Barnes) all track how decolonisation questioned Western knowledge and expertise, but also how geographers benefitted from the winding down of empire by 'careering' - moving around and taking up new roles in late colonial and postcolonial places and institutions. At the same time, many of the expatriate geographers who found new positions as teachers and researchers in postcolonial times lived in fluid political situations and often with a fear of dispossession and deportation. Such anxiety spurred them to become interested in the geography of the decolonising world as a geography shaped by questions of permanence, transience and vulnerability. Geographers such as Pélissier, Seck and Spate were acutely concerned with how secure the livelihoods and communities of the people they studied were, and with the unprecedented intrusion of the modern (late colonial and postcolonial) state and capital into their lives through development and modernisation projects that had deleterious environmental impacts and unhinged traditional land-holding and social structures. 
Some of the themes addressed have a broader resonance in contemporary 'decolonial' theory and scholarship on vernacular culture and the indigenisation of knowledge, and again with figures such Pélissier and Spate (and a larger cast of fieldworkers not considered in these essays) soliciting and seeking to incorporate 'indigenous' knowledge into their accounts and offering an implicit criticism of statesanctioned initiatives. To be sure, there was a romanticism to this endeavour - an indigenist mentality and yearning that was Eurocentric and toyed with primitivism - but it also served as a political project 'for the people' and native groups (living in countries as far apart as Senegal and Fiji) knew that they could use Western academics to get their voices and concerns heard in official circles. On the other hand, Pélissier's peasant atlas project in French West Africa (Suremain) was executed under the watchful eyes of colonial and then postcolonial state censors, and amidst tumultuous processes of political upheaval, dislocation and conflict.

The authors highlight the repertoire of geographical skills, strategies and networks at play in how geographers operated in spaces of decolonisation, and how they enabled them to subvert established norms and cultivate their own niches in the interstices of flux and transformation. The geographer's art and craft comes to the fore, whether those concerned were negotiating a better deal for the Ahmadiyas of 'Undivided India' (Fitzpatrick), seeking to indigenise the geography curriculum (Craggs and Neate), negotiating the bloody civil wars in Mozambique and Angola in ways that helped to retain the structures of 'tropical geography' (Sarmento), politicising the geographically inflected 'determinism' in tropical French Africa (Suremain), or having their ideas and methods usurped to advance American Area Studies projects that were geared to Cold War data gathering and surveillance (Child and Barnes). At the same time, some of the papers remind us that geographers were not always in the thick of things. American Area 
Studies proceeded largely without geographers, and there was no specialist geographer helping the Indian side at the boundary deliberations of 1947, with vital consequences for how the border was ultimately delimited.

Turning now to some of the distinct threads in the papers and the broader questions they raise, Craggs and Neate show how the 'careering' of geographers was deeply implicated in late colonial and decolonial imperatives in Nigeria, and how geography was both transmitted from metropole to colony, and 'came home' to shape the nature and content of the discipline taught in Britain. They explore the valuable relationships that evolved between native Nigerian and expatriate British geographers as they criss-crossed the ends of empire, and thus how decolonisation was registered and activated through academic research and careers, institutional sites and developments and transnational networks. They acknowledge the selective and hierarchical nature of these careering networks. 'Careering' therefore brought to the fore the pragmatism of geographical inquiry and the development of Nigerian elites through their recruitment and training at the University of London. Somewhat in contrast to the anti-colonial positioning and radical political commitment to engage locally of the likes of Buchanan, we might question how directly the geographical research arising from such 'careering' engaged with and influenced political decision making, either in London or Nigeria. Ironically, Buchanan and Pugh's Land and People in Nigeria (1955) remained a generic text on the country and its future through the 1960s, and while it extolled the benefits of agricultural modernisation, it was silent about the great political opportunities afforded by decolonisation. With the rise of the quantitative revolution in geography, research focused on land-use, population density and economic and regional disparity became central to the discussions on the postcolonial development of Nigeria, yet decolonisation 
in this instance did not simply involve the influx of Western geographical models, but also a shift from a colonial to a local - 'indigenised' and 'Africanised' - curriculum.

Hannah Fitzpatrick provides a necessary corrective to the established discourse on the partition of Undivided India. She reveals the hitherto unnoticed role that Spate, cartography and maps played in the delineation of the boundaries between the two nascent states of India and Pakistan. Her paper raises the important question of why the parties led by the Indian National Congress did not feel the need to include a geographer in this exercise, and whether the consequences of partition might have been any less disturbing and destructive had more geographers been involved in weighing up conflicting factors of terrain, coastal access, infrastructure, resources, and the distribution of different ethnic and religious communities and minorities. She also dwells on the minutiae of political expediency in the run up to Partition, and how a hegemonic geopolitical project of nation building gripped and sidelined putatively more equitable modes of geographical (boundary making) deliberation. The paper provides novel insights into Spate's little-known and serendipitous links to the Ahmadiyyas and the Pakistani Muslim League, and how his concerns about the use of maps and categories of contiguity, ethnicity and religious affiliation continue to rankle the peace and tranquillity of the subcontinent. Spate sensed that the partition of the subcontinent was ultimately a legal rather than geopolitical matter, and that contentious and conflicting data were subordinated to this legality and the state-based nationalism it licensed and sought to regiment on the ground. His intuitions about the innate lack of congruence between the state and the nation continue to plague Pakistan as a postcolonial nation.

Fitzpatrick uses Spate's geography, and the moment of independence, to probe the norms and biases of official and revisionist colonial and postcolonial historiography, including Spate's own writing. There is the official view, endorsed by Pakistan, that 
Hindus and Muslims are separate entities or nations and that both must have statehood. The second view is the official stand of the Congress Party, which does not question the assumption that nations must turn into states but denies that Hindus and Muslims are distinct nations. The transfer of power took precedence over boundary making, which resulted in the subordination of geography, and particularly of contiguity, to the rhetoric of partition and communalism. It is argued within the quotidian existence of an average Indian or Pakistani that neither side could come to trust the impartial principles and intentions of the other. The Partition of India was one of political-legal negotiation over nationhood, and its accommodation of economic, cultural and political aspirations remains incomplete. We thus return to the spectre of decolonisation as an unfinished project, and currently with the Kartarpur Corridor for the Sikhs being jointly developed after seventy-two years of inaction, and the Qadian's of the Ahmadiyyas continuing to suffer persecution despite the significant efforts of geographers like Spate to avert that fate.

The paper by Elliot Child and Trevor Barnes is in some ways an outlier in this collection, in that it does not deal directly with geography and geographers. Its value, however, lies in its alternative take on geography and decolonisation from the standpoint of the USA as a post-war imperial actor that forged 'an empire without colonies' by filling what was seen as the power vacuum (and potentially dangerous void) left by retreating European colonial powers and the threat posed by an expanding communism. The filling of this void was aided and abetted by a specific type of gazetteering-cumgovernmentalised geographical knowledge, and spatialising project - Area Studies arising from the behavioural, social and human sciences but from which geography, in a disciplinary sense, was largely excluded. This morphing of geographical studies into 
Area Studies facilitated internationalism, and an internationalism geared foremost to American interests.

Knowledge production based on a detailed and in-depth understanding of the diverse regions of the world, and with a view to keeping communism at bay, involved a mastery of languages, culture, politics, economics and social conditions, and Area Studies thus became a vehicle for ensnaring decolonising territories and projects in American geopolitical and ideological designs. Child and Barnes note that the absence, for the most part, of geographers in these programmes was in direct contrast to their deeply embodied knowledge and understanding of empire. They trace how Area Studies programmes were geared to 'colonising' the 'empty spaces' or 'great gaping holes' in the world, and how this provided the basis for a sustained, secretive and muscular geopolitical propaganda that was indulged in by the Soviet Union too. It also provided the justification for the projection of American 'soft power' across vulnerable regions of the world. The Area Studies programmes that developed between the 1940s and 1960s were military, bureaucratic and corporate enterprises that were supported by patronage funding from US government departments and a plethora of non-governmental agencies and wealth private donors, and geography lost out to other more instrumentalist disciplines, such as anthropology, sociology and related behavioural sciences. These projects were aided and abetted by the Central Intelligence Agency and United States Agency for International Development, and promulgated what W.W. Rostow called a 'non-Communist manifesto' from Iran to Guatemala. Area Studies fought a covert war of attrition in decolonising societies, and with American insistence on trade (rather than aid), democracy and free markets serving as the basis for what was soon termed the development of underdevelopment'. 
João Sarmento uncovers the politics and practices of Portuguese geographers in Europe's longest-lasting colonial empire, and one headed by an authoritarian state. Tracking the Lisbon School of Geography across the late colonial and postcolonial period, and with original interview data and a strong gender dimension to the paper, the tenor is that geographers' lives and professional activities were largely subsumed by the decolonisation process, culminating in the bloody civil wars of the 1970s which all but ended the Mozambique- and Angola-focused tropical geography of the Lisbon geographers, led by Orlando Ribeiro. The paper draws examples from the lives and works of three geographers: Ribeiro, who focused on humanised landscapes and humanenvironment relationships in the tradition pioneered by Pierre Gourou, and with the concept of Lusotropicalism, which melded geography, race and culture to justify Portugal's ongoing colonial presence in Africa at a time when countries all around were gaining independence; and his proteges Carlos Alberto Medeiros and Isabel Marques Medeiros.

The paper also provides insights into the careers of three women geographers, Maria Eugenia Moreira, Celeste Coelho and Maria Clara Mendes, and their role in ensuring that 'tropical geography' continued to be taught. Sarmento is interested in their role in reasserting the racialised virtues of 'white settlement' in Mozambique. However, over time and with decolonisation imminent, these geographers became more aware of the inequities of the Portuguese colonial system, and had to adapt to the way degree programmes, educational provision and doctoral research were revolutionised by the postcolonial state. He shows that, in important respects, geographers from Portugal did not have the same opportunities to invest in and reflect on the decolonisation process as those in Nigeria, Dakar, India, Malaysia, Singapore or Senegal. The decolonisation of 
the Portuguese Empire in the 1970s was abrupt, and quickly brought tropical geography to an end. Fieldwork was curtailed and dissertations were finished back in Lisbon.

Marie-Albane de Suremain reviews the intricate and contested relationship that existed between French scientific research centres studying 'tropical Africa' before and after independence in the early 1960s. Geographers such as Pélissier and Seck (the first indigenous Senegalese geographer) arguably came closest to producing what we might call a geography of decolonisation. It was incumbent upon them, Suremain notes, to produce apolitical and objective studies. France, its colonial administrations, and their postcolonial successor states drew a line between science and politics. But it was a crooked line, and one that was difficult to produce and sustain. French geographers' struggles with 'political reserve', and in some cases determination to take sides, shines through Suremain's narrative, and an interesting question thus arises from her study: is geography any more or less insightful, critical or progressive when it starts from a position of detachment and neutrality, and lets political and ethical issues into the frame, or when it embarks from a political platform that is geared to change or revolution and then seeks to present its findings and arguments as dispassionate or even-handed? Suremain's paper provides a useful reminder that while this question is often cast in either/or terms, it comes out in messy and hybrid forms, making the issue of what counts as a politics of geographical knowledge in situations of decolonisation a complex and contingent matter.

The scientific bodies with which Suremain is concerned strove to be apolitical and mindful of the limits to their engagements with people and place, and they venerated this 'scientific' orientation because it took scholarship and fieldwork in professionalised disciplines such as geography away from the clutches of the military, antiquated colonial administrators and populist and zealously nationalist connections between geography 
and empire expedited by national and regional geographical societies. There are parallels here to Child and Barnes's paper, in that Area Studies programmes also sought a handson, fieldwork- and fact-based 'scientific' analysis of decolonising, but in a different context. French state-funded scientific institutions and research centres envisioned a purportedly 'neutral' research programme, divested of erstwhile colonial objectives and hubris, as a means of putting a respectable face on colonial occupation and then of managing decolonisation.

Suremain's paper also highlights the nuanced ambivalence associated with 'tropical geography' as a frame of reference. The absence of 'native' Africans from this research endeavour is a major issue, and remaining 'apolitical' was a ruse that geographers used to distance themselves from claiming to 'speak for the other'. While many of these geographers sought to distance themselves from colonial perspectives, and rued the environmental and social damage wrought by empire, they continued to essentialise Africa - as peasant, rural, traditional - and as locked in a condition of 'backwardness' on account of the tropical environment. At the same time, their embrace of terroir valorised traditional knowledge systems over the technical and managerial knowledge of the modern colonial and postcolonial state. Suremain thus shows how French geographers negotiated a decolonising Africa by muddying the boundaries of coloniality within the traditions of 'doing' geography.

\section{The spatiality of decolonisation}

A historical lens on the liaison between geography and decolonisation has largely been missing from geography's postcolonial, and perhaps now decolonial, 'turns' and the ways in which they seek to radically re-position understanding of the politics and poetics 
of geographical inquiry, and especially the whiteness, masculinism and overwhelming Eurocentrism (collectively, we might say, colonialist hue) of the discipline. To reiterate, the historical perspectives developed in this special issue are limited in scope. They provide but a starting point for further discussion about what it means to talk about a geography 'in' or 'of' decolonisation.

Finally, they also perhaps provide a starting point for further thinking about the broader spatiality of decolonisation, and, concomitantly, the biases and limitations in the ways post-war geographers conceived it. As Margaret Kohn and Keally McBride acknowledge, questions of time and temporality have long been the lodestars of scholarship and theory on decolonisation as an event, project and process that anticipates, enacts and celebrates and laments itself. ${ }^{35}$ Questions of time and temporality are central to both the imperialist's (duplicitous) concern with preservation and continuity, and in the late colonial era with 'managed' demise and exit (the promise yet persistent delay of independence, and the conceit that the transfer of power was a sign a moral strength on the part of the imperial power rather than an admission of their weakness or wrongdoing, and rightful yearning on the part of the colonised), and to the immense pressure that postcolonial states and leaders were under to bring about rapid change. Decolonisation was a matter of velocity, and a rupture in time.

Furthermore, a prodigious body of anti-colonial thought revolves around the ways in which colonisers and the colonised were locked in an all-encompassing struggle over the disposal of time. Marxist anti-colonial thought dwells on the enslaved and subjugated labour time of the colonised, which, it is argued, was the backbone of European wealth and superiority. Fanon, offering a broader cultural and psychological

\footnotetext{
${ }^{35}$ See M. Kohn and K. McBride, Political Theories of Decolonization, Oxford, 2011, 20-24.
} 
reading, wrote of the dead time of the colonial condition (the utter lack of possibility it presented) and how it at once drove and imperilled the extirpative and utopian thrust of anti-colonial resistance. ${ }^{36}$ The protracted time of anti-colonial struggle - encapsulated in both the figure of the guerrilla fighter (or partisan) who defeats the imperial enemy by not losing (by holding her/his ground and suspending the time of military confrontation in the face of superior military might), and the idea of non-violent resistance as a pledge to lead a different life and truth - were central motifs too. ${ }^{37}$ Postcolonial thought is variously concerned with the 'belated' and 'secondary' time of postcoloniality: the way newly independent nations and cultures only gain their freedom 'after' Europe and in a position 'behind' Europe; with the paradoxical time of the postcolonial nation's 'return in the archaic' (appeals to a pristine and mythic pre-colonial past that had been partly vanquished and partly invented by colonisers for their own ends); with metropolitan anxiety about the consequences of imperial decline and its sublimation in imperialist nostalgia; and with the turning of the postcolonial world into a 'conscript' of Western civilisation and modernity. ${ }^{38}$

That work on decolonisation, up to and including the above noted resurgence of historical interest in the subject, has emanated chiefly from outside geography, has perhaps been a contributing factor in this hegemony of time. Critical appreciation of the spatiality of decolonisation has come in understated ways, and without an extended dialogue with geographers, then or since. Yet it is not hard to find in these vistas a

\footnotetext{
${ }^{36}$ Fanon, The Wretched of the Earth, 2-17; also see F. Fanon, CEuvres, Paris, 2011, Introduction by M. Bessone.

${ }^{37}$ See H. Caygill, On Resistance: A Philosophy of Defiance, London, 2013, 104-115; S. Scheipers, Unlawful Combatants: A Genealogy of the Irregular Fighter, Oxford, 2015.

${ }^{38}$ See Asad, Conscripts of western civilization?, L. Ghandi, Postcolonial Theory: A Critical Introduction, New York, 1998; G. Prakash, The modern nation's return in the archaic, Critical Inquiry 23 (1997) 536-556; R. Rosaldo, Imperialist nostalgia, Representations 26 (1989) 107-122; D. Scott, Conscripts of Modernity: The Tragedy of Colonial Enlightenment, Durham NC, 2004.
} 
supplementary - indeed mutually constitutive - set of spatial relations and geographical concerns, some of which were articulated by geographers in the post-war era.

In Fanon's dialectical vision, 'Decolonization, which sets out to change the order of the world, is clearly an agenda for total disorder. But it cannot be accomplished by the wave of a magic wand, a natural cataclysm, or a gentleman's agreement. Decolonisation, we know, is an historical process: In other words, it can only be understood, it can only find its significance and become self coherent insofar as we can discern the historymaking movement which gives it form and substance'.${ }^{39}$ But this history-making is also a space-making (and clearing) endeavour: 'By penetrating its geographical configuration and classification we shall be able to delineate the backbone on which the decolonized society is reorganized.... And it's true there is not one colonized subject who at least once a day does not dream of taking the place of the colonist' ${ }^{40}$ Fanon's language of place and space (birth and berth) plays a pivotal role in his conception of how and why Western values and practices need to be critiqued, reclaimed and usurped. His writing is replete with 'quarters' and 'zones' of division, segregation, envy and confrontation, and examines how decolonisation is fundamentally a project of re-positioning at all scales from the body and home to the global hierarchy of states, histories and norms.

And Fanon is by no means the only anti-colonial or decolonial thinker to invoke the elementary spatiality of coloniality and decolonisation. Some of his spatial repertoire is now refracted through the work of thinkers such as Mbembe. In basic terms - and geographers at the time grasped this - the lives and fortunes of those caught up in decolonisation hinged on the seizure, control, security, mastery, vulnerability, arrangement, loss and reconfiguration of homes, livelihoods, communities, landscapes,

\footnotetext{
${ }^{39}$ Fanon, Wretched of the Earth, 2.

${ }^{40}$ Fanon, Wretched of the Earth, 2-5.
} 
territories, borders, ecologies, populations, resources, and rural and urban, coastal and interior, ways of life. Kohn and McBride have identified the material and existential facets of land and environment as a 'revolutionary foundation' of decolonisation. ${ }^{41}$ There is no space here to probe the myriad ways in which such ideas about the braiding of the temporality and spatiality of decolonisation might be harnessed. But to be sure, the geographers and geographies pursued in this special issue point to this wider opportunity to return to the history of post-war decolonisation to think further about decolonisation and the decolonial in terms of space as well as time.

\footnotetext{
${ }^{41}$ Kohn and McBride, Political Theories of Decolonization, vii.
} 